\title{
The real static behaviour of historic bridge in town Krásno nad Kysucou in Slovakia
}

\author{
Miroslav Strieška ${ }^{1, *}$, Peter Koteš ${ }^{1}$, and Petra Bujňáková ${ }^{1}$ \\ ${ }^{1}$ University of Žilina, Faculty of civil engineering, Univerzitná 8215/1, 01026 Žilina, Slovakia
}

\begin{abstract}
The paper is focused on real static behaviour of the oldest reinforced concrete arch bridge in middle Europe, which is located in the town Krásno nad Kysucou over the river Bystrica. This bridge was diagnosed and the task was to determine the load-carrying capacity of the bridge. Documentation of the object has not been available, so, it was not clear what the static schema of the bridge is - whether it is fixed arch or two-hinged arch and whether the spandrel walls located on the both sides in the longitudinal direction are cooperating with the arch. The paper is focused on the static calculation and the load-carrying capacity calculation in order to compare various static schemas.
\end{abstract}

\section{Introduction}

There are situated many old bridges in Slovakia, some of them have historical significance, but one of the most important bridges in middle Europe is the oldest reinforced concrete arch bridge, which is located in the town Krásno nad Kysucou [1]. It is a two span Monier type bridge structure, which has operated since 1892. In the frame of research activities of the Department of structures and bridges, University of Zilina, the bridge was diagnosed and, consequently, it was needed to verify its real static behaviour and to determine loadcarrying capacity $[2,3]$. It is not known the exact (real) static schema of the bridge and also it is not known how the spandrel walls are cooperating with the arch concerning the very old bridge structure (more than 124 years). Because the static schema of the bridge and the spandrel walls cooperating with the arch have considerable impact on the load-carrying capacity, that paper is focused on the most precise calculation in order to determine the real behaviour of bridge structure.

\section{Description of the real state of the construction}

The bridge consists of two reinforced concrete arches, which are built on two stone abutments and one stone pier. Its two spans have clear span as much as $16.8 \mathrm{~m}[4,5]$

The thickness of the arch changes in the transverse direction as well as the longitudinal direction. The thickness in the longitudinal direction is changed from $400 \mathrm{~mm}$ in the arch spring to $200 \mathrm{~mm}$ in the middle of the first arch (arch top) and $190 \mathrm{~mm}$ in the arch top of the second arch. The thickness of $400 \mathrm{~mm}$ is the same in the springs of the arches, but the

* Corresponding author: miroslav.strieska@,fstav.uniza.sk 
thickness in the top of the arches (middle span) in the transverse direction is variable from $250 \mathrm{~mm}$ to $150 \mathrm{~mm}$ in the middle of first arch and from $250 \mathrm{~mm}$ to $130 \mathrm{~mm}$ in the middle of second arch. This thickness variability in the transverse direction is gradually disappeared from the middle to the quarter of the arch. There is concrete overlay with plain concrete above the base arch, which has reinforcement in both surfaces. The overlay reaches a thickness up to $600 \mathrm{~mm}$ in the arch springs and decreases to the $1 / 3$ of span about $[4,5]$.

During the diagnostic of the bridge [6,7], crack was found in the middle of the second arch through its height and width of cross-section, the cracks were also located between the arch and the spandrel walls through the whole longitudinal direction.

\section{Static calculation - load-carrying capacity}

The paper is focused on the load-carrying capacity calculation of the bridge structure [8] according to the provision USM 01/2012 [9], which was valid at the time of diagnostic and calculation. Subsequently, percentage of load capacity was recalculated according to current code STN EN 1991-2 [10].

The arches were simulated in Scia Engineer software as 3D slab-wall model. Measured geometric parameters of arches and spandrel walls were applied in the model simulation.

In order to analyse the real static behaviour of the bridge and be able to prove the crack formation and development in the middle of the second arch (formation of plastic hinge), it was necessary to create several models to see, which one describes the best the real bridge structure [11].

The first simulations considered fixed arch. To compare the cooperation of spandrel walls with the arch, there were created three models of fixed arch (Fig. 1), where the spandrel walls were connected to the arch as:

- fixed spandrel walls to the arch,

- hinge connection to the arch,

- model without spandrel walls (the spandrel walls were simulated as a load).

In other models, there was considered the hypothesis of two hinged arch with hinge connection of spandrel walls to the arch or model of two hinged arch without spandrel walls, and it was considered in both cases:

- without concrete overlay,

- with concrete overlay.

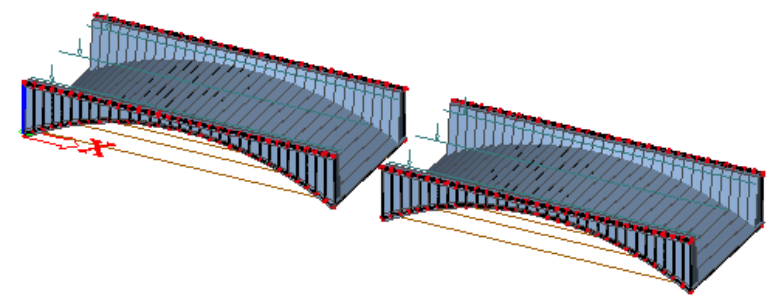

a) The model - spandrel walls cooperate with the arch 


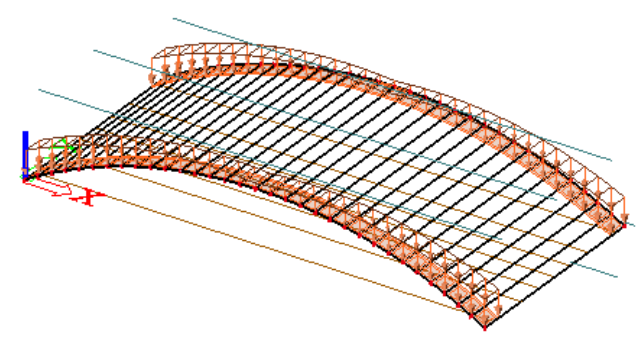

a) The model without spandrel walls (the spandrel walls were modelled as a load)

Fig. 1. The models of arches.

Altogether, it was seven basic models (Fig. 1). In first three models (fixed arch), the most critical cross section were in the arch springs. These models could not show formation of crack in the middle of the arch but it proved that the arch is two hinged arch. Model without spandrel walls, where spandrel walls were simulated as load (fixed arch model), showed that cross section in the spring arch cannot even carry dead weight as well as two hinged arch model without the spandrel walls cannot even carry dead weight in the middle of the arch. In means that spandrel walls have to cooperate with the arches (Tables 1 and 2). As there was found crack between the arch and spandrel walls during the diagnostic of the bridge, it can be assumed that the spandrel walls are hinge connected to the arches.

Considering that it is variable thickness of the arch and also that the spandrel walls cooperate with the arch, it was appropriate to calculate buckling length by the stability calculation in Scia Engineer software. It means that it is a stability problem [12,13,14].

Because it is combination of bending moment and normal (compressive) force, it was needed to make analysis of cross-section by iteration method (step by step procedure) in such a way that the load was simulated in successive steps by $10 \%$ of variable load according to USM 01/2012 [9] as well as STN EN 1991-2 [10]. Subsequently, the crosssection in the middle, in the quarter and in the arch spring were verified by iterative calculation by changing the percentage of variable load for each cross section using interactive diagram.

\subsection{Variable load according to provision USM 01/2012}

According to the provision USM 01/2012 [9], it was necessary to consider the old load models in accordance with the expired Slovak standard - ZZI, ZZII and four axle vehicle. The examples of the critical load ZZI location and four axle vehicle location for normal load-carrying capacity and exclusive load-carrying capacity are show in Fig. 2. The final load-carrying capacity of individual models are shown in Tables 1 and 2 (normal $Z_{N}$ and exclusive $\mathrm{Z}_{\mathrm{E}}$ load-carrying capacity). 

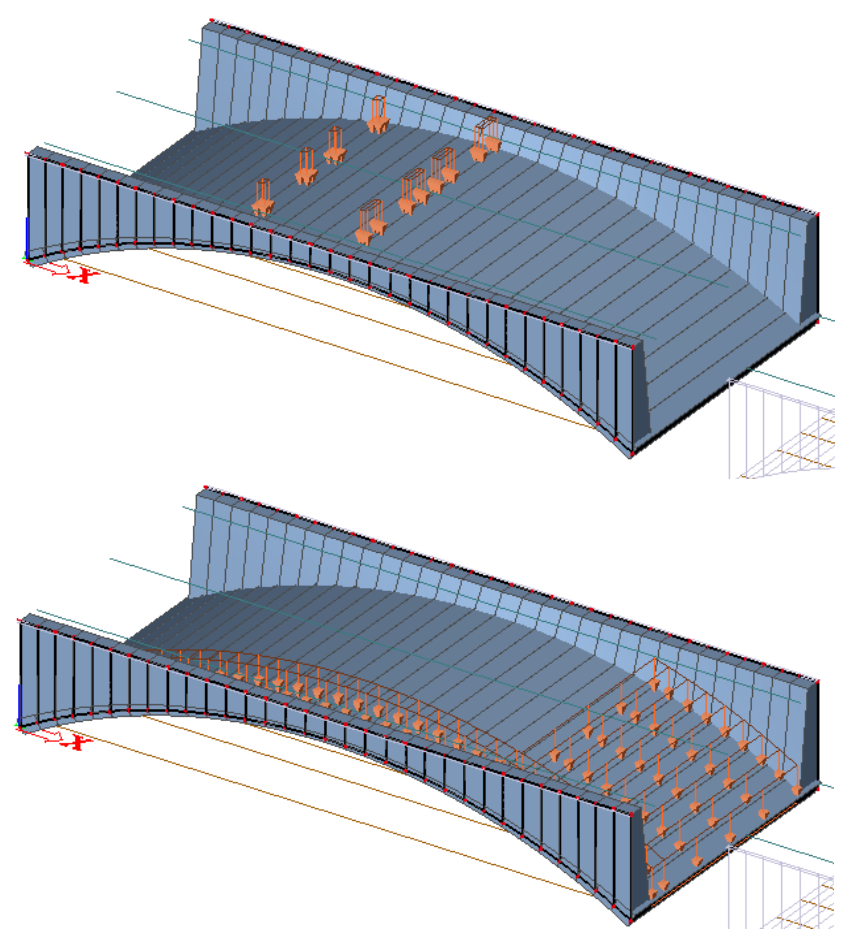

a) Load: ZZI in the middle of the arch

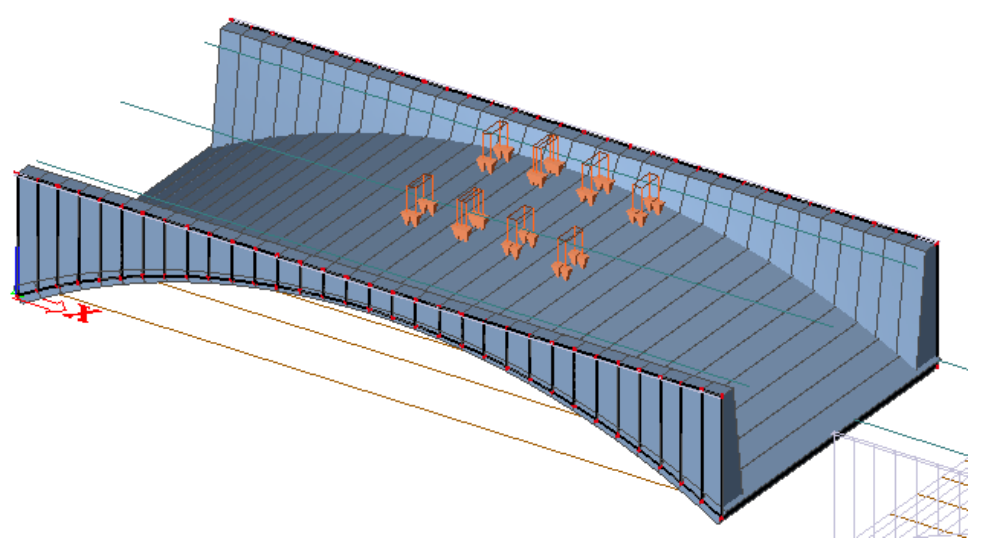

b) Load: four axle vehicle in the middle of the arch

Fig. 2. Examples of load location according to the guideline USM 01/2012 [9].

The fixed arch model with hinge connection of spandrel walls to the arch has normal load-carrying capacity of $Z_{N}=19.2$ tons and exclusive load-carrying capacity of $Z_{E}=24.0$ tons, which are relatively small values. This load-carrying capacity $Z_{N}$ would be exceeded during the service life. This means that the crack would be created in the arch spring (formation of plastic hinge - model of two hinged arch). The model of two hinged arch with hinge connection of spandrel walls to the arch without overlay has the most critical cross-section in the quarter of the span, but not in the middle of the arch (in the middle of the span). Concerning that the crack was found in the middle of the second arch and not in the quarter of the arch, it can be concluded that the concrete overlay with plain 
concrete above the base arch is cooperating with the arch. It indicates that the model, which describes the best the actual construction is the model of two hinged arch with hinge connection of spandrel walls to the arch with concrete overlay, because, in this case, critical cross section is in the middle of the arch, which can leads to the crack (formation of plastic hinge). The normal load-carrying capacity of the first arch (without the crack in the middle of the arch) is $Z_{N}=22.4$ tons and exclusive load-carrying capacity is $Z_{E}=48.0$ tons.

Table 1. Normal load-carrying capacity ZN in tones [t].

\begin{tabular}{|c|c|c|c|}
\hline Static schema & $\begin{array}{l}\text { arch } \\
\text { spring }\end{array}$ & $\begin{array}{c}\text { quarter } \\
\text { of the arch }\end{array}$ & $\begin{array}{c}\text { middle } \\
\text { of the arch }\end{array}$ \\
\hline fixed arch model, fixed spandrel walls to the arch & $32.0 \mathrm{t}$ & $32.0 \mathrm{t}$ & $25.6 \mathrm{t}$ \\
\hline $\begin{array}{l}\text { fixed arch model, hinge connection of spandrel walls to } \\
\text { the arch }\end{array}$ & $19.2 \mathrm{t}$ & $32.0 \mathrm{t}$ & $22.4 \mathrm{t}$ \\
\hline fixed arch model, without spandrel walls & $0.0 \mathrm{t}$ & $19.2 \mathrm{t}$ & $19.2 \mathrm{t}$ \\
\hline two hinged arch model, without spandrel walls & $32.0 \mathrm{t}$ & $0.0 \mathrm{t}$ & $0.0 \mathrm{t}$ \\
\hline $\begin{array}{l}\text { two hinged arch model, without spandrel walls with } \\
\text { concrete overlay }\end{array}$ & $32.0 \mathrm{t}$ & $9.6 \mathrm{t}$ & $0.0 \mathrm{t}$ \\
\hline $\begin{array}{l}\text { two hinged arch model, hinge connection of spandrel } \\
\text { walls to the arch }\end{array}$ & $32.0 \mathrm{t}$ & $12.8 \mathrm{t}$ & $22.4 \mathrm{t}$ \\
\hline $\begin{array}{l}\text { two hinged arch model, hinge connection of spandrel } \\
\text { walls to the arch with concrete overlay }\end{array}$ & $32.0 \mathrm{t}$ & $28.8 \mathrm{t}$ & $22.4 \mathrm{t}$ \\
\hline
\end{tabular}

Table 2. Exclusive load-carrying capacity ZE in tones [t].

\begin{tabular}{|c|c|c|c|}
\hline Static schema & $\begin{array}{c}\text { arch } \\
\text { spring }\end{array}$ & $\begin{array}{c}\text { quarter } \\
\text { of the arch }\end{array}$ & $\begin{array}{c}\text { middle } \\
\text { of the arch }\end{array}$ \\
\hline fixed arch model, fixed spandrel walls to the arch & $48.0 \mathrm{t}$ & $80.0 \mathrm{t}$ & $64.0 \mathrm{t}$ \\
\hline $\begin{array}{c}\text { fixed arch model, hinge connection of spandrel walls to } \\
\text { the arch }\end{array}$ & $24.0 \mathrm{t}$ & $80.0 \mathrm{t}$ & $56.0 \mathrm{t}$ \\
\hline fixed arch model, without spandrel walls & $0.0 \mathrm{t}$ & $48.0 \mathrm{t}$ & $48.0 \mathrm{t}$ \\
\hline two hinged arch model, without spandrel walls & $48.0 \mathrm{t}$ & $0.0 \mathrm{t}$ & $0.0 \mathrm{t}$ \\
\hline $\begin{array}{c}\text { two hinged arch model, without spandrel walls with } \\
\text { concrete overlay }\end{array}$ & $48.0 \mathrm{t}$ & $16.0 \mathrm{t}$ & $0.0 \mathrm{t}$ \\
\hline $\begin{array}{c}\text { two hinged arch model, hinge connection of spandrel } \\
\text { walls to the arch }\end{array}$ & $80.0 \mathrm{t}$ & $24.0 \mathrm{t}$ & $48.0 \mathrm{t}$ \\
\hline $\begin{array}{c}\text { two hinged arch model, hinge connection of spandrel } \\
\text { walls to the arch with concrete overlay }\end{array}$ & $80.0 \mathrm{t}$ & $64.0 \mathrm{t}$ & $48.0 \mathrm{t}$ \\
\hline
\end{tabular}

Subsequently, two other models of second arch were created in Scia Engineering software, which represented the arch with crack (in the middle of the arch). The crack was simulated like hinge. This means that static schemas were three-hinged arch with hinge connection of spandrel walls to the arch (one model with concrete overlay and another one without concrete overlay). Moreover, the load-carrying capacity of the second arch was calculated. The results of load-carrying capacity of these models are shown in Table 3.

Table 3. Load-carrying capacity.

\begin{tabular}{|c|c|c|c|}
\hline Static schema & $\begin{array}{c}\text { arch } \\
\text { spring }\end{array}$ & $\begin{array}{c}\text { quarter } \\
\text { of the arch }\end{array}$ & $\begin{array}{c}\text { middle } \\
\text { of the arch }\end{array}$ \\
\hline \multicolumn{3}{|c|}{ Normal load-carrying capacity $\mathrm{Z}_{\mathrm{N}}$} \\
\hline $\begin{array}{c}\text { three hinged arch model, hinge connection of spandrel } \\
\text { walls to the arch }\end{array}$ & $28.8 \mathrm{t}$ & $6.4 \mathrm{t}$ & $32.0 \mathrm{t}$ \\
\hline $\begin{array}{c}\text { three hinged arch model, hinge connection of spandrel } \\
\text { walls to the arch with concrete overlay }\end{array}$ & $28.8 \mathrm{t}$ & $22.4 \mathrm{t}$ & $32.0 \mathrm{t}$ \\
\hline \multicolumn{3}{|c|}{ Exclusive load-carrying capacity $\mathrm{Z}_{\mathrm{E}}$} \\
\hline three hinged arch model, hinge connection of spandrel & $64.0 \mathrm{t}$ & $8.0 \mathrm{t}$ & $56.0 \mathrm{t}$ \\
\hline
\end{tabular}




\begin{tabular}{|c|c|c|c|}
\hline walls to the arch & & \\
\hline $\begin{array}{c}\text { three hinged arch model, hinge connection of spandrel } \\
\text { walls to the arch with concrete overlay }\end{array}$ & $64.0 \mathrm{t}$ & $48.0 \mathrm{t}$ & $56.0 \mathrm{t}$ \\
\hline
\end{tabular}

\subsection{Variable load according to the code STN EN 1991-2}

In this case, the bridge was loaded according to current Eurocode STN EN 1991-2 [10], specifically load models: LM1, LM2 and LM4. The load-carrying capacity of the cross section was recalculated on the most efficient loads locations. This Eurocode was not intended for calculation of the load-carrying capacity of the bridge in time of calculation. This is reason why the percentage of variable load of each cross section was used and needed to compare (the cross section in the middle of the arch, in the quarter of the arch and in the arch spring). The results of percentage load-carrying capacity of these models are given in Table 4. For example, the most efficient location load (load model LM1) is shown in the Fig. 2.

Table 4. Load-carrying capacity of the arch recalculated according to STN EN 1991-2 [6].

\begin{tabular}{|c|c|c|c|}
\hline Static schema & $\begin{array}{l}\text { arch } \\
\text { spring }\end{array}$ & $\begin{array}{c}\text { quarter } \\
\text { of the arch }\end{array}$ & $\begin{array}{c}\text { middle } \\
\text { of the arch }\end{array}$ \\
\hline fixed arch model, fixed spandrel walls to the arch & $70 \%$ & $100 \%$ & $80 \%$ \\
\hline $\begin{array}{l}\text { fixed arch model, hinge connection of spandrel walls } \\
\text { to the arch }\end{array}$ & $20 \%$ & $80 \%$ & $50 \%$ \\
\hline fixed arch model, without spandrel walls & $0 \%$ & $50 \%$ & $40 \%$ \\
\hline two hinged arch model, without spandrel walls & $60 \%$ & $0 \%$ & $0 \%$ \\
\hline $\begin{array}{l}\text { two hinged arch model, without spandrel walls with } \\
\text { concrete overlay }\end{array}$ & $60 \%$ & $20 \%$ & $0 \%$ \\
\hline $\begin{array}{l}\text { two hinged arch model, hinge connection of spandrel } \\
\text { walls to the arch }\end{array}$ & $100 \%$ & $30 \%$ & $50 \%$ \\
\hline $\begin{array}{l}\text { two hinged arch model, hinge connection of spandrel } \\
\text { walls to the arch with concrete overlay }\end{array}$ & $100 \%$ & $60 \%$ & $50 \%$ \\
\hline
\end{tabular}

Also, in this case (according to STN EN 1991-2 [10]), the static behaviour of the bridge was similar to the previous case (USM 01/2012 [9]). The results of simulated models show that model of two hinged arch with hinge connection of spandrel walls to the arch with concrete overlay describes the best the real static behaviour of the first arch. And the model of three hinged arch with hinge connection of spandrel walls to the arch with concrete overlay describes the best the real static behaviour of the second arch (where crack was formed in the middle of the arch).

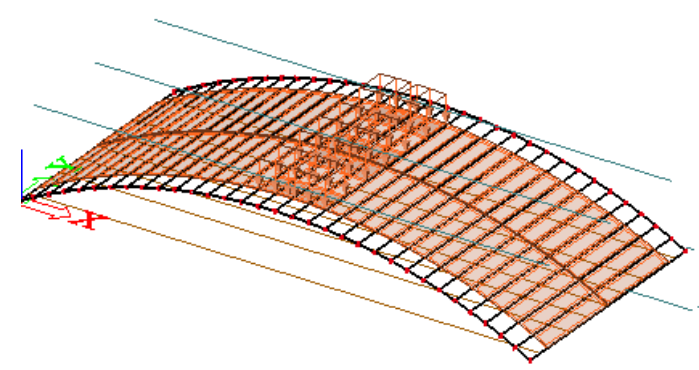

Fig. 3. Example of location of load model LM1 in the middle of the arch according to the code STN EN 1991-2 [10] 


\section{Conclusion}

The simulated models showed the real static behaviour of the oldest reinforced concrete arch bridge in the middle of Europe. The paper presents the results of numerical models.

This paper demonstrated that the real static behaviour of the bridge is similar in both calculation, according to the provision USM 01/2012 as well as according to the current code STN EN 1991-2. Moreover, it was also shown that the model of two hinged arch with hinge connection of spandrel walls to the arch with concrete overlay proves the crack formation and development in the middle of the second arch (formation of plastic hinge).

Recalculation of load-carrying capacity was based on these static schemas and the results are as follows:

- the first arch: the static schema is two hinged arch with hinge connection of spandrel walls to the arch with concrete overlay (normal load-carrying capacity is 22.4 ton and exclusive load-carrying capacity is 48.0 ton),

- the second arch: the static schema is three hinged arch with hinge connection of spandrel walls to the arch with concrete overlay (normal load-carrying capacity is 22.4 ton and exclusive load-carrying capacity is 48.0 ton).

The research is supported by the Slovak Research and Development Agency under contract No. APVV-14-0772, and by Research Project No. 1/0566/15 of Slovak Grant Agency.

\section{References}

1. P. Paulík, Bridges in Slovakia, JAGA, Bratislava, 258 (2012)

2. J. Antucheviciene, Z. Kala, M. Marzouk, E.R. Vaidogas, Math. Prob. in Eng. 16(2015), 362579 (2015)

3. J. Antucheviciene, Z. Kala, M. Marzouk, E.R. Vaidogas, Math. Prob. in Eng. 3(2015), 160569 (2015)

4. P. Paulík, M. Bačuvčík, M. Brodňan, P. Koteš, Beton TKS 5, 30-34 (2015)

5. P. Paulík, P. Koteš, J. Vičan, M. Bačuvčík, 9th sem. „Sanation of Concrete Structures“, 73-78 (2015)

6. I. Holly, J. Bilcik, In App. Mech. and Mat., 206-209 Svratka, ČR (2015)

7. J. Bilcik, I. Holly, Proc. Eng. 65, 248-253 (2013)

8. M. Strieška, Recalculation and reconstruction of reinforced arch bridge in Krásno nad Kysucou, diploma thesis, Žilina, 268, (2016)

9. USM 01/2012, Load-carrying capacity of bridges (2012)

10. STN EN 1991-2, Eurocode 2: Design of concrete structures - Part 1-1: General rules and rules for buildings, National Annex (SÚTN, Bratislava, 2006)

11. V. Benko, L. Fillo, P. Kendický, V. Knapocová, In App. Mech. and Mat., 747-752, Svratka, ČR (2015)

12. J. Vican, J. Gocal, J. Odrobinak, R. Hlinka, Communications 15/4, 27-31 (2013)

13. J. Vican, J. Odrobinak, J. Gocal, R. Hlinka, Bridges in Danube basin Bridges, 267-278 (Springer Fachmedien, Wiesbaden, 2013)

14. J. Vican, J. Odrobinak, J. Gocal, Communications 18/4, 3-9 (2016) 